\title{
Rola związków glinu w stabilizowaniu skał ilasto-łupkowych
}

\section{The role of aluminum compounds in stabilizing clay shale rocks}

\author{
Małgorzata Uliasz \\ Instytut Nafty i Gazu - Państwowy Instytut Badawczy
}

\begin{abstract}
STRESZCZENIE: W większości rejonów kraju, w których prowadzone są prace poszukiwawcze, przekrój jednostek geologicznych odznacza się przewagą skał ilasto-łupkowych. Skały te łatwo ulegają zjawiskom dyspersji lub pęcznienia, jak również wykazują uszkodzenie struktury w postaci szczelin i mikroszczelin. W związku z tym, są one często źródłem występowania nieprzewidzianych trudności wynikających z braku stateczności ściany otworu wiertniczego uniemożliwiającej niekiedy osiągnięcie planowanej jego głębokości. Stateczność ściany otworu wiertniczego rozpatrywana jest najczęściej w dwóch aspektach, tj. mechanicznym, w ramach którego analizowane są siły i ciśnienie działające na ścianę otworu oraz fizykochemicznym, dotyczącym oddziaływania płuczki wiertniczej na przewiercane warstwy. Dużą rolę w stabilizowaniu skał ilasto-łupkowych przypisuje się jednak fizykochemicznemu oddziaływaniu płuczki wiertniczej. Zarówno badania laboratoryjne, jak i doświadczenia przemysłowe dowodzą, że odpowiedni dobór składu płuczki wiertniczej mający wpływ na jej właściwości reologiczno-strukturalne i inhibitujące, ułatwia sterowanie przebiegiem procesów fizykochemicznych zachodzących w układzie skała ilasta-płuczka wiertnicza. W warunkach otworowych do przewiercania skał ilasto-łupkowych różniących się składem mineralogicznym oraz właściwościami fizyczno-mechanicznymi stosowana jest głównie płuczka o potrójnym inhibitowaniu zawierająca w składzie inhibitor jonowy - $\mathrm{KCl}$ oraz dwa organiczne inhibitory polimerowe - PHPA i poliglikol. Jednym z nowszych kierunków badań laboratoryjnych przeprowadzonych w INiG-PIB było wykorzystanie w składzie płuczki związków glinu w połączeniu z kwasami organicznymi, tj. huminowym i fulwowym. Kompozycja tych środków w składzie opracowanej płuczki pełniła rolę podstawowego, nieorganicznego inhibitora polimerowego - Al-KHF, zwanego stabilizatorem łupków. Jego mechanizm oddziaływania na skały łupkowe polega na blokowaniu ich por przez powstałe osady $\mathrm{Al}(\mathrm{OH})_{3}$ i flokuły kwasu humusowego. W odpowiednich warunkach otworowych powstałe wytrącenia osadzając się w porach i mikroszczelinach tworzą fizyczną barierę, która blokuje dostęp wody/filtratu i zapobiega wzrostowi w nich ciśnienia. W artykule przedstawione zostały wyniki wybranych metod badawczych, na podstawie których określono wpływ opracowanej płuczki wiertniczej zawierającej stabilizator glinowy oraz płuczki stosowanej w warunkach otworowych na stabilność łupków różniących się zawartością frakcji ilastej. Analiza wyników badań wykazała, że w zależności od właściwości hydrofilowych skał ilasto-łupkowych, do ich przewiercania może być stosowana płuczka wiertnicza zawierająca Al-KHF zarówno z dodatkiem, jak i bez dodatku glikolu.
\end{abstract}

Słowa kluczowe: płuczka wiertnicza, warstwy ilasto-łupkowe, stateczność ściany otworu, stabilizator łupków, kompleksowy wodorotlenek glinu.

ABSTRACT: In most regions of the country where exploration is carried out, the cross-section of geological units is characterized by the predominance of clay and shale rocks. These rocks can easily disperse or swell; they also show structural damage in the form of crevices and micro-fractures. Therefore, they are often a source of unforeseen difficulties resulting from the lack of stability of the borehole wall, which sometimes prevents it from reaching its planned depth. The borehole wall stability is most often considered in two aspects, i.e. mechanical, which analyzes the forces and pressure acting on the borehole wall, and physicochemical, regarding the impact of the drilling fluid on the drilled layers. However, a significant role in stabilizing shale rocks is attributed to the physicochemical impact of drilling mud. Both laboratory tests and industrial experiments prove that the proper selection of drilling mud composition influencing its rheological and structural as well as inhibiting properties facilitates controlling the course of physicochemical processes occurring in the clay rock - drilling mud system. In borehole drilling of clay-shale rocks differing in mineralogical composition as well as physical and mechanical properties, a triple-inhibited drilling mud containing ionic inhibitor - $\mathrm{KCl}$ and two organic polymer inhibitors - PHPA and polyglycol is used. One of the newer directions of laboratory tests conducted at INiG - PIB was the use of aluminum compounds in the drilling mud composition in combination with organic acids, i.e. humic and fulvic acids. The composition of these agents in the composition of the developed drilling mud played the role of the basic, inorganic polymer inhibitor - Al-KHF, called the shale stabilizer. Its mechanism of impact on shale rocks consists in blocking their pores by the resulting $\mathrm{Al}(\mathrm{OH}) 3$ deposits and humic acid flocculates. Under appropriate borehole conditions, the resulting precipitates, forming in pores and micro-fractures, create a physical barrier that

Autor do korespondencji: M. Uliasz, e-mail: malgorzata.uliasz@inig.p1

Artykuł nadesłano do Redakcji: 15.10.2019 r. Zatwierdzono do druku: 23.12.2019 r. 
blocks water/filtrate access and prevents pressure build-up. The article presents the results of selected research methods on the basis of which the influence of the developed drilling mud containing aluminum stabilizer and the mud used in borehole conditions on the stability of shales with different clay content was determined. Analysis of the test results showed that depending on the hydrophilic properties of clay shale, a drilling mud containing Al-KHF with or without glycol may be used to drill them.

Key words: drilling mud, clay-shale formations, borehole wall stability, shale stabilizer, complex aluminum hydroxide.

\section{Wprowadzenie}

Utrzymanie stateczności ściany otworu w warstwach ilasto-łupkowych w dużym stopniu zależy od płuczki wiertniczej stanowiącej wieloskładnikowy układ koloidalno-dyspersyjny, charakteryzujący się określonymi właściwościami reologiczno-strukturalnymi i inhibitującymi, wielkością filtracji, gęstości i pH. Najbardziej niekorzystny wpływ na skały ilasto-łupkowe wywiera faza wodna płuczki wiertniczej, która w wyniku różnorodnych procesów (filtracja, dyfuzja, osmoza, kapilarne zasysanie) przenika do przewiercanej skały wywołując znaczny spadek jej wytrzymałości mechanicznej na skutek hydratacji. Ważne znaczenie ze względu na ograniczanie hydratacji skał ilasto-łupkowych ma uszczelnianie mikroszczelin i szczelin istniejących w skale bądź tworzących się podczas jej przewiercania. W tym celu używane są specjalne środki chemiczne, nazywane także stabilizatorami łupków, które uszczelniają szczeliny i mikroszczeliny w skale ilasto-łupkowej, a także hydrofobizują osad filtracyjny i zmniejszają jego przepuszczalność, ograniczając tym samym wnikanie filtratu z płuczki do skały. Mechanizm ich działania przyczynia się do odizolowania ciśnienia w otworze od ciśnienia porowego w skale, ułatwiając utrzymywanie stateczności ściany otworu wiertniczego (Raczkowski i Półchłopek, 1998). Takim działaniem na skały ilasto-łupkowe charakteryzują się m.in.: poliglikol, środki asfaltowe, szkło wodne oraz kompleksowe związki glinu.

W przypadku stosowania poliglikolu, podstawowe znaczenie ma zjawisko separacji faz, polegające na jego wytrącaniu się w postaci mikrokropelek powyżej temperatury zmętnienia. Osadzając się na powierzchni skał i przenikając do ich przestrzeni porowej w wyniku różnicy ciśnień, tworzy powłokę hydrofobową oraz wypełnia pory ograniczając migrację filtratu z płuczki do skały. Działanie stabilizujące środków asfaltowych związane jest $\mathrm{z}$ osadzaniem się ich cząstek na ścianie otworu oraz wnikaniem do szczelin i mikroszczelin łupku, tworząc barierę dla migracji filtratu. W przypadku stosowania szkła wodnego, na ścianie otworu i w porach skał w warunkach obniżonego $\mathrm{pH}$, powstaje nieprzepuszczalna dla wody struktura żelowa kwasu krzemowego i nierozpuszczalne osady związków utworzone w reakcji krzemianów z wielowartościowymi jonami (Uliasz et al., 2006). Natomiast wykorzystane w składach płuczek związki glinu, w obecności wody złożowej o niskim $\mathrm{pH}$ zawierającej $\mathrm{Na}^{+}, \mathrm{Ca}^{2+}, \mathrm{Mg}^{2+}$, ulegają wytrąceniu do postaci spolimeryzowanych form $\mathrm{Al}(\mathrm{OH})_{3}$, które osadzając się w porach i szczelinach blokują dostęp filtratu oraz zmniejszają przenoszenie ciśnienia porowego. Ze względu na dodatni ładunek elektryczny mogą również adsorbować się na powierzchni pakietów minerałów ilastych ograniczając ich hydratację.

Glin wyróżnia się złożonym chemizmem zależnym od pH i zdolnością do tworzenia licznych kompleksów o różnym stopniu hydratacji ze względu na jego duży ładunek i mały promień $(0,57 \AA)$. Roztwory wodne większości soli glinu są kwaśne wskutek hydrolizy jonów $\mathrm{Al}^{3+}$. Podczas dodawania do roztworu danej soli zasady np. $\mathrm{NaOH}$, jon $\mathrm{Al}^{3+}$ reaguje $\mathrm{z} \mathrm{NaOH}$ do wyczerpania jonów $\mathrm{OH}$ tworząc biały galaretowaty osad wodorotlenku glinu - $\mathrm{Al}(\mathrm{OH})_{3}$. W początkowej fazie złożonego procesu otrzymywania wodorotlenku glinu w obecności zasady, przy wartości roztworu $\mathrm{pH}$ poniżej 3, powstaje hydrokompleks $\mathrm{Al}\left(\mathrm{H}_{2} \mathrm{O}\right)_{6}^{3+}\left(\mathrm{zwany}^{3 l^{3+}}\right)$. W wyniku jego hydrolizy, gdy wartości pH roztworów wynoszą od 3 do 5 , otrzymywane są polikationowe formy glinu $\mathrm{Al}\left(\mathrm{H}_{2} \mathrm{O}\right)_{5}(\mathrm{OH})^{2+}$ (jako $\left.\mathrm{Al}(\mathrm{OH})^{2+}\right)$ i $\mathrm{Al}\left(\mathrm{H}_{2} \mathrm{O}\right)_{4}(\mathrm{OH})^{2+}$ (jako $\mathrm{Al}(\mathrm{OH})_{2}^{+}$) oraz różne wielopierścieniowe (zawierające dwa lub więcej atomów glinu) kationy. Przy wartościach pH pomiędzy 5 i 6 rozpoczyna się wytrącanie $\mathrm{Al}$ jako $\mathrm{Al}(\mathrm{OH})_{3}$. W roztworach o $\mathrm{pH}$ powyżej 8 osad $\mathrm{Al}(\mathrm{OH})_{3}$ ulega rozpuszczeniu z utworzeniem tetrahydroksyglinowego anionu $\mathrm{Al}(\mathrm{OH})_{4}^{-}$jako związku dominującego (Minczewski i Marczenko, 1985; Benaissa et al., 1997; Ramirez et al., 2005). Na rodzaj otrzymanych produktów hydrolizy wpływać może wiele czynników, m.in.: temperatura oraz zawartość elektrolitów, takich jak $\mathrm{Ca}^{2+} \mathrm{i} \mathrm{Mg}^{2+}$ jak również kwasów organicznych. Powstały osad wodorotlenku glinu łatwo rozpuszcza się w kwasie oraz w nadmiarze zasady - lecz tylko po wytrąceniu. W czasie starzenia rozpuszczalność wodorotlenku glinu stopniowo zmniejsza się ze względu na powstawanie mostków tlenowych między sąsiadującymi atomami glinu (Reed, 1972; Krupińska, 2011).

\section{Wykorzystanie właściwości związków glinu w technologii płuczek inhibitowanych}

Skały ilasto-łupkowe występujące na obszarze Polski w przekroju różnych jednostek geologicznych są bardzo zróżnicowane ze względu na skład mineralogiczny oraz właściwości fizyczno-mechaniczne. Biorąc pod uwagę ich zachowanie się w czasie przewiercania i wystąpienie ewentualnych 
komplikacji wiertniczych wywołanych oddziaływaniem płuczki to wg ogólnej klasyfikacji dzielą się one na: kruche, uwodnione lub plastyczne oraz pęczniejące (Czerwińska i Półchłopek, 1971; Raczkowski et al., 1987). W związku z tym, w zależności od procentowego udziału zawartych w nich minerałów ilastych reprezentowanych przez grupy smektytów, illitów, chlorytów i kaolinitów w reakcji z filtratem z płuczki wiertniczej mogą wykazywać uszkodzenie struktury w postaci szczelin i mikroszczelin, ulegać dyspersji lub powiększać swoją objętość. Dlatego bardzo ważny jest dobór rodzaju inhibitorów hydratacji skał ilasto-łupkowych w składach płuczek wiertniczych stosowanych do ich przewiercania. Oprócz znanych inhibitorów hydratacji skał ilasto-łupkowych, w składach inhibitowanych płuczek wiertniczych można wykorzystać także kompleksowe związki chemiczne zawierające jony glinu.

Jednym z takich związków, który opracowany został pod koniec lat 90. XX wieku i wykorzystany do sporządzania inhibitowanych płuczek wiertniczych o unikatowych parametrach reologiczno-strukturalnych, jest polichlorek wodorotlenku magnezowo-glinowego. Ten syntetyczny kompleksowy związek nieorganiczny (jako produkt handlowy) ma postać krystalicznego drobno zmielonego proszku, który nie rozpuszcza się w wodzie, lecz tworzy zawiesinę koloidalną. W krajowym wiertnictwie związek ten o nazwie VISPLEX został wykorzystany w składzie płuczki wiertniczej zastosowanej do przewiercania utworów fliszowych i miocenu. Natomiast zastosowany w składzie płuczki wiertniczej, tzw. bentonitowo-wodorotlenkowej opracowanej w INiG - PIB (Raczkowski et al., 1996), sporządzony został w warunkach laboratoryjnych przy użyciu soli glinu i magnezu oraz wodorotlenku sodu. Otrzymany związek chemiczny - wodorotlenek magnezowo-glinowy (WMG) w postaci galeretowatego osadu, zawierający jednakowe ilości jonów $\mathrm{Al}^{3+} \mathrm{i} \mathrm{Mg}^{2+}$, pełnił rolę zagęstnika nieorganicznego i łącznie $\mathrm{z}$ bentonitem stanowił podstawowy składnik strukturotwórczy tej płuczki. WMG posiadający dodatni ładunek elektryczny, adsorbując się na ujemnie naładowanych powierzchniach cząstek bentonitu tworzy struktury koagulacyjne, często nazywane „kruchym żelem”, o silnie wyrażonych właściwościach tiksotropowych. Płuczkę bentonitowo-wodorotlenkową, charakteryzującą się „odwróconą reologią”, wyróżnia od płuczek polimerowych profil przepływu w przestrzeni pierścieniowej. Płynięcie płuczki następuje w strefie przyłożonego naprężenia ścinającego, natomiast poza zasięgiem jego działania płuczka pozostaje w stanie żelu. Warstwa nieruchomej płuczki - „martwa strefa”, która tworzy fizyczną barierę przy ścianie otworu przyczynia się do zmniejszenia filtracji oraz chroni skały słabo zwięzłe przed erozją. Stanowi to jeden z czynników korzystnie oddziaływujący na stateczność ściany otworu. Kolejnym czynnikiem zabezpieczającym tego typu skały przed hydratacją to kationowy charakter wodorotlenku magnezowo-glinowego i małe rozmiary cząsteczki. Adsorbując się w przestrzeni międzypakietowej minerałów ilastych tworzy warstwę w postaci formy krystalicznej i staje się niewymiennym tzw. polimerem nieorganicznym, ograniczającym dostęp filtratu do przestrzeni porowej skał.

W nowej generacji związków glinu dominującą rolę w stabilizowaniu skał ilasto-łupkowych charakteryzujących się mikroszczelinowością, odgrywa kompleks wodorotlenku glinu, który można otrzymywać w reakcji kwaśnych soli glinu z wodorotlenkiem sodu lub przez obróbkę zasadowych roztworów glinianu sodu kwasem organicznym. Mechanizm inhibitującego działania $\mathrm{Al}(\mathrm{OH})_{3}$ jako stabilizatora łupków, szczególnie kruchych i mikroszczelinowatych, polegać może na zmianie ich właściwości fizyczno-chemicznych. W warunkach otworowych, w obecności wody złożowej zawierającej $\mathrm{Na}^{+}, \mathrm{Ca}^{2+}, \mathrm{Mg}^{2+}$ i wartości $\mathrm{pH}$ poniżej 6, ulegając wytrąceniu jako formy polikationowe może, jak podaje literatura (Ramirez et al., 2005; Zhang et al., 2013a, 2013b; Chao et al., 2014; Arambulo et al., 2015), osadzać się w porach i szczelinach blokując dostęp wody i zmniejszać przenikanie ciśnienia w porach. Nie wyklucza się również, że spolimeryzowana forma Al zawierająca sześcioczłonowe pierścienie o ładunku dodatnim może adsorbować się na powierzchni pakietów minerałów ilastych tworząc warstwy ośmiościanów, które redukują ich ładunek ujemny. Utworzone warstwy zbudowane z sześcioczłonowych pierścieni wiążą się z powierzchnią pakietów wiązaniami wodorowymi i nie ulegają wymianie kationowej ograniczając tym samym hydratację minerałów ilastych (Reed, 1972). W zależności od warunków złożowych występujących w przewiercanych warstwach, wytrącony wodorotlenek glinu może w początkowej fazie występować jako amorficzny osad, a następnie przekształcać się w krystaliczną postać alotropową stając się częścią struktury tych warstw, która powinna wspomagać ich stabilizowanie i blokować dostęp wody do porów zapobiegając pęcznieniu.

Osady wodorotlenków glinu otrzymywane w reakcji alkalicznego glinianu sodu - $\mathrm{NaAlO}_{2}$ z kwasami organicznymi kompleksującymi, uznawane są za nisko toksyczne. Stosowane w technologii płuczkowej, opracowane zostały z wykorzystaniem kwasów fulwowych i huminowych, które tworzą stabilne kompleksy z glinem. W wyniku ich reakcji z alkalicznym glinianem powstają sole sodowe kwasów huminowych i fulwowych. Otrzymane związki chemiczne określane są jako nowa generacja kompleksowego wodorotlenku glinu - AHC (Aluminum Hydroxide Complex) lub HA-Al (Humic AcidAluminum). Nowy rodzaj nisko toksycznych stabilizatorów łupków wykorzystano w składach płuczek wiertniczych stosowanych do przewiercania warstw łupków o zróżnicowanym stopniu pęcznienia występujących m.in. na obszarze Amazonii, Algierii i akwenach Morza Północnego (Benaissa et al., 1997; Ramirez et al., 2005; Zhang et al., 2013a, 2013b). 
Substancje humusowe to najbardziej rozpowszechniona w przyrodzie grupa związków organicznych, które powstają w wyniku działania mikroorganizmów oraz wydzielanych przez nie enzymów. Na podstawie licznych i zaawansowanych prac badawczych wykazano (Pastuszko, 2007; Krupińska, 2012; Siebielska et al., 2014), że struktura tych substancji zawiera kilka pierścieni aromatycznych, które połączone są z szeregiem grup funkcyjnych, jak: karboksylową, fenolową i hydroksylową. Biorąc pod uwagę dużą różnorodność tych wielkocząsteczkowych związków o masie w zakresie od 700 do 800000 , dokonano ich podziału ze względu na rozpuszczalność. Ogólny podział substancji humusowych to: kwasy fulwowe - rozpuszczalne w wodzie w całym zakresie $\mathrm{pH}$, kwasy huminowe - rozpuszczalne w wodzie o $\mathrm{pH}$ w zakresie alkalicznym, huminy występujące $\mathrm{w}$ glebie - nierozpuszczalne w wodzie w całym zakresie $\mathrm{pH}$ oraz kwasy hymatomelanowe występujące w wodach podziemnych - rozpuszczalne w alkoholu. Kwasy huminowe to związki wielkocząsteczkowe o masie cząstek $50000-100000$, natomiast kwasy fulwowe zaliczane są do związków małocząsteczkowych, których masa wynosi od 500 do 2000 (Krupińska, 2012). Masa cząsteczkowa tych związków ma wpływ na szybkość wiązania protonów i metali, a także zdolność do adsorpcji oraz migracji w środowisku. Substancje humusowe o niższej masie cząsteczkowej cechuje szybszy proces sorpcji oraz większa ruchliwość, natomiast o większej masie cząsteczkowej wykazują większą zdolność wiązania metali.

Kompleks wodorotlenku glinu HA-Al (Humic Acid - Aluminium), otrzymywany na osnowie glinianu sodu i kwasu huminowego, rozpuszczalny w płuczce wiertniczej wytwarza aniony tetrahydroksyglinianowe $-\mathrm{AI}(\mathrm{OH})_{4}^{-}$, które generują jej pH w zakresie od 10 do 12 , w zależności od ilości HA-Al. Przy odpowiedniej zawartości HA-Al w płuczce, w porach i mikroszczelinach łupków nasyconych wodą złożową o $\mathrm{pH}<6$ zawierającą elektrolity, z alkalicznego filtratu powinien wytrącać się osad $\mathrm{Al}(\mathrm{OH})_{3}$ oraz flokuly kwasu huminowego blokujące dostęp wody do ich przestrzeni, redukując tym samym ciśnienie w porach skał strefy przyotworowej (Zhang et al., 2013a, 2013b).

Płuczki wiertnicze zawierające kompleks wodorotlenku glinu w kombinacji z organicznymi inhibitorami polimerowymi jako podstawowe ich składniki zaliczane są do płuczek HPWBM (high performance water based mud) wykazujących podwyższą zdolność inhibitowania hydratacji skał ilasto-łupkowych. Przykładem takiej płuczki, opracowanej przez firmę Baker Hughes, jest system płuczkowy PERFORMAX (Dye et al., 2004; Baker Hugnes, 2010).

\section{Ocena wpływu związków glinu na właściwości inhibitujące płuczki wiertniczej w świetle badań laboratoryjnych}

Podstawowym środkiem wykorzystanym do opracowania w INiG - PIB płuczki na osnowie stabilizatora glinowego był roztwór glinianu sodu - SAX 18 charakteryzujący się wysokim $\mathrm{pH}$, około 13. Do obniżenia $\mathrm{pH}$ roztworu glinianu sodu i utworzenia osadów związków glinu wykorzystano chlorki poliglinu -ALCAT (pH 1) i PAX 1881-25-2 (pH około 3,5), a także kwasy organiczne jak: octowy oraz mieszaninę huminowego i fulwowego zawartych w substancji humusowej- Humix. W pierwszej kolejności przeprowadzono szereg wstępnych badań polegających na ustaleniu ilości tych środków w wodzie dla uzyskania odpowiedniego pH płuczki, jak i wizualizacji powstawania produktów ich reakcji. W sporządzonych roztworach wodnych zawierających wytypowane środki i dodatkowo obrobionych $5 \% \mathrm{KCl}$, stwierdzono wytrącanie się w nich osadów lub zawiesin stanowiących produkty reakcji glinianu sodu z zadanym środkiem chemicznym (rys. 1). Wytrącenia osadów w postaci drobinek lub kłaczków obserwowano również w interakcji wybranych wodnych roztworów tych związków z solanką złożową o $\mathrm{pH} 5,2$ zawierającą między innymi ok. $400 \mathrm{mg} / \mathrm{dm}^{3} \mathrm{Ca}^{2+}$ i $60 \mathrm{mg} / \mathrm{dm}^{3} \mathrm{Mg}^{2+}$ (rys. 2).

W oparciu o uzyskane wstępne wyniki badań do opracowania składu płuczki wiertniczej wytypowano zestaw

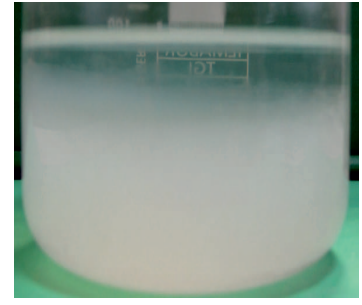

A. $\mathrm{H}_{2} \mathrm{O}+1 \% \mathrm{SAX}-18$

$+1 \%$ ALCAT $+5 \% \mathrm{KCl}$ $\mathrm{pH}-9,6$

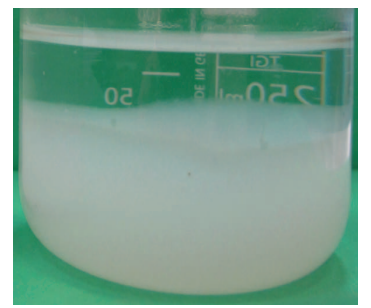

B. $\mathrm{H}_{2} \mathrm{O}+2 \% \mathrm{SAX}-18$ $+1 \% \mathrm{CH}_{3} \mathrm{COOH}$ $\mathrm{pH}-10,1$

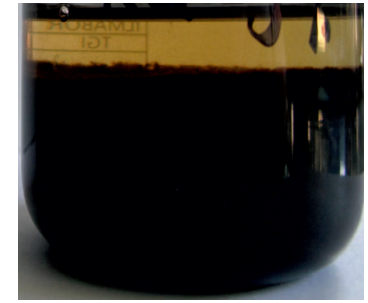

C. $\mathrm{H}_{2} \mathrm{O}+1 \% \mathrm{SAX}-18$

$+1 \%$ ALCAT $+0,5 \%$

HUMIX $+5 \% \mathrm{KCl}$ $\mathrm{pH}-10,1$

Rys. 1. Produkty reakcji glinianu sodu z zadanymi środkami chemicznymi

Fig. 1. Reaction products of sodium aluminate and specific chemicals

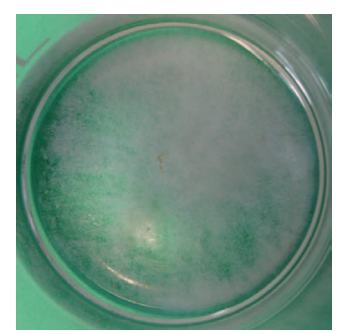

Rys. 2. Wtrącenia powstałe $\mathrm{w}$ interakcji solanki złożowej z roztworami B i C

Fig. 2. Inclusions resulting from the interaction of reservoir brine with solutions $\mathrm{B}$ and $\mathrm{C}$ 
wybranych środków chemicznych jak: roztwór glinianu sodu (SAX $18-1 \%$ ) wraz z roztworem chlorku poliglinu (ALCAT - 0,5\%) i substancją organiczno-mineralną stanowiącą mieszaninę kwasów huminowych i fulwowych (HUMIX - 1\%). Kompozycja tych środków jako stabilizator glinowy pełniła rolę podstawowego, nieorganicznego inhibitora polimerowego - Al-KHF. Ustalone doświadczalnie ilości środków rozpuszczano w wodzie słodkiej, do której dodawano koloidy ochronne (Rotomag, Polofix LV), biopolimer, $\mathrm{KCl}$ i blokator. Użyte do jej sporządzenia środki chemiczne i koloidy wykazywały synergistyczne działanie tworząc jednorodny i stabilny w czasie system płuczki o właściwościach tiksotropowych, która łatwo ulegała upłynnianiu pod wpływem naprężeń ścinających. Sporządzona płuczka charakteryzowała się także odpornością na wysoką temperaturę, pełne zasolenie, skażenia zwiercinami oraz, w dopuszczalnych granicach, solami metali dwuwartościowych.

Przeprowadzona seria badań laboratoryjnych określająca właściwości inhibitujące płuczki zawierającej w składzie nieorganiczny inhibitor polimerowy - stabilizator glinowy (Al-KHF) oraz inhibitor jonowy - $\mathrm{KCl}(5 \%)$, w dwustopniowym teście dyspersji wykazała, że jej bezpośrednie oddziaływanie na wzorcową skałę ilasto-łupkową reprezentowaną przez łupek mioceński zapobiegało jego dyspersji. Odzyskiwane ilości tego łupku po dyspersji w płuczce wynosiły ponad $90 \%$. Natomiast znacznie mniejsze jego ilości odzyskano w drugim etapie testu, po dyspersji w wodzie, które wynosiły maksymalnie około $20 \%$. W związku z tym, w celu ograniczenia dyspersji łupku na tym etapie badań, w składzie płuczki zastosowano organiczny inhibitor polimerowy, jak poliglikol (PG) lub PHPA. Na podstawie uzyskanych wyników kolejnej serii badań laboratoryjnych stwierdzono korzystniejszy wpływ poliglikolu niż PHPA na właściwości reologiczno-strukturalne i inhibitujące płuczki wiertniczej. Synergizm działania poliglikolu i stabilizatora glinowego w środowisku płuczki wiertniczej spowodował znaczną poprawę jakości odzyskiwanych próbek skał i ich ilości, a w szczególności po dyspersji w wodzie, która wynosiła ponad 50\% (rys. 3 i 4).

Analiza uzyskanych wyników badań laboratoryjnych wykazała, że ze względu na fizyczno-chemiczny mechanizm oddziaływania na łupek Al-KHF, znormalizowane metody badawcze służące do oceny właściwości inhibitujących organicznych inhibitorów polimerowych, w niewystarczającym stopniu przybliżają działanie nieorganicznych inhibitorów polimerowych (stabilizator glinowy, szkło wodne) w warunkach otworowych. Właściwości inhibitujące płuczki na osnowie kompozycji związków glinowych i humusowych należy rozpatrywać poprzez efektywność blokowania por skał łupkowych, szczelinowatych przez powstałe osady $\mathrm{Al}(\mathrm{OH})_{3}$ i flokuły kwasu humusowego. Powstałe, w kontakcie z przewiercanymi skałami nasyconymi wodą złożową o niskim $\mathrm{pH}$, wytrącenia osadzając się w porach i mikroszczelinach powinny tworzyć fizyczną barierę blokującą dostęp wody i zapobiegać wzrostowi ciśnienia porowego.
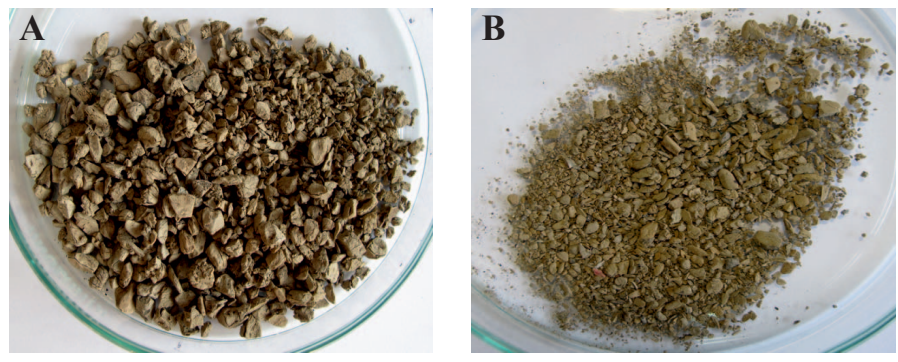

Rys. 3. Łupek mioceński po dyspersji w płuczce zawierającej Al-KHF (A) i w wodzie (B)

Fig. 3. Miocene shale after dispersion in drilling mud containing Al-KHF (A) and in water (B)
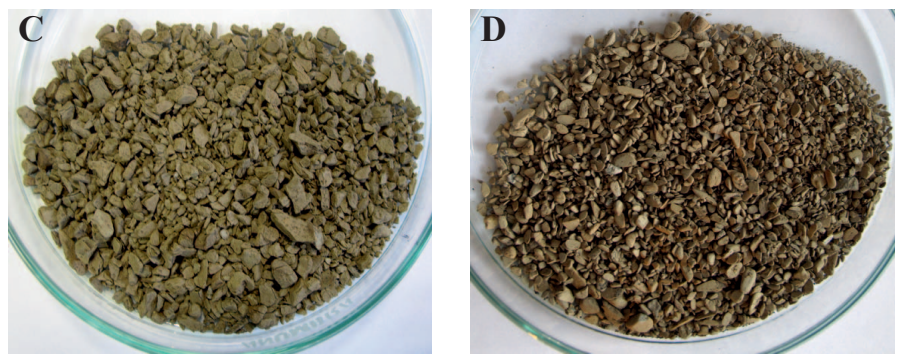

Rys. 4. Łupek mioceński po dyspersji w płuczce zawierającej $\mathrm{Al}-\mathrm{KHF}+\mathrm{PG}(\mathbf{C})$ i w wodzie (D)

Fig. 4. Miocene shale after dispersion in drilling mud containing $\mathrm{Al}-\mathrm{KHF}+\mathrm{PG}(\mathrm{C})$ and in water (D)

W związku z tym zastosowano inną metodę badawczą polegającą na określeniu przenikania, transmisji ciśnienia porowego przez próbkę skały. Próbne testy przeprowadzono na zbudowanym stanowisku badawczym (rys. 5), wykorzystując próbkę skały o przepuszczalności $53,7 \mathrm{mD}$ i porowatości mieszczącej się w zakresie 6-9\%. Przez użytą do badań próbkę skały przetłaczano w czasie 24 godz. solankę złożową o pH około 4,4 zawierającą $2400 \mathrm{mg} / \mathrm{dm}^{3}$ jonów $\mathrm{Ca}^{2+}$ i $850 \mathrm{mg} / \mathrm{dm}^{3}$ jonów $\mathrm{Mg}^{2+}$,

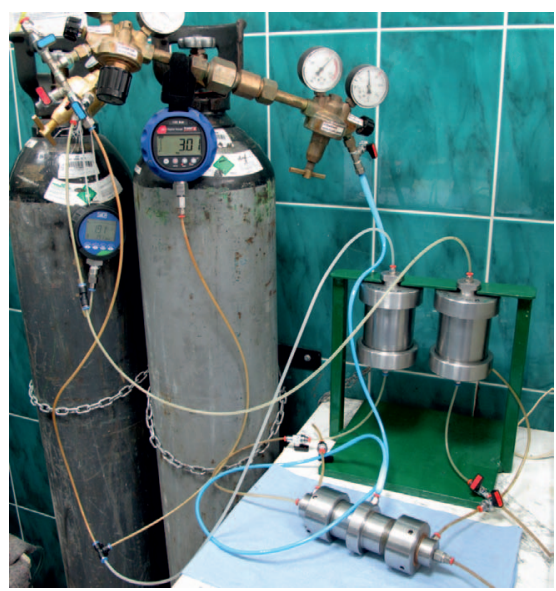

Rys. 5. Stanowisko badawcze do oznaczania transmisji ciśnienia w porach skał

Fig. 5. Test stand for the determination of pressure transmission in rock pores 
a następnie przy stałym ciśnieniu 0,2 $\mathrm{MPa}$ przetłaczano płuczkę o pH 10,6 zawierającą Al-KHF oraz płuczkę o $\mathrm{pH}$ 9,2 dodatkowo skażoną jonami $\mathrm{Ca}^{2+} \mathrm{i} \mathrm{Mg}^{2+}$. Do badań zastosowano również płuczkę krzemianową na osnowie szkła sodowego o pH 10,9 charakteryzującą się porównywalnym mechanizmem inhibitującego działania na skały ilasto-łupkowe. Przepływające przez próbkę skały filtraty z wytypowanych płuczek wiertniczych powodowały wzrost ciśnienia na wylocie, które rejestrowano za pomocą miernika ciśnienia. Próbki skał pod ciśnieniem przetrzymywano do czasu osiągnięcia na wylocie ciśnienia $0,2 \mathrm{MPa}$.

Jak wykazały badania czas transmisji ciśnienia
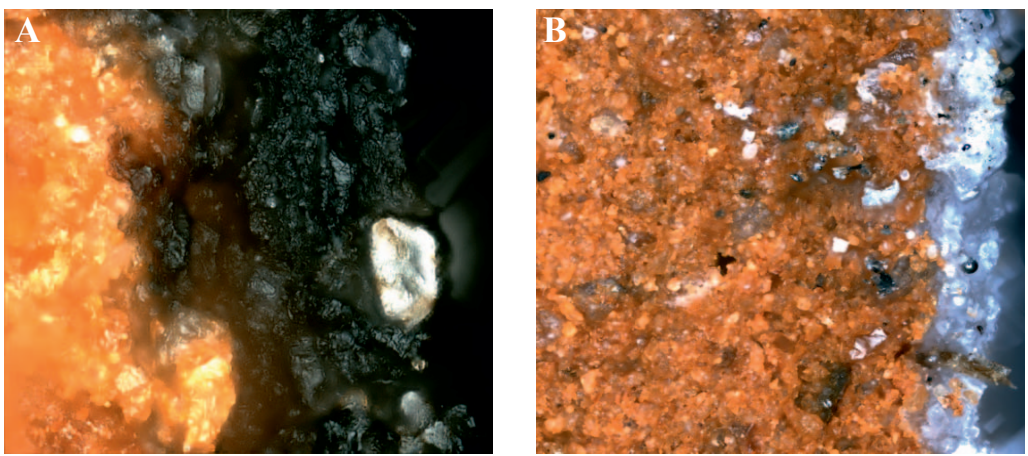

Rys. 7. Widok osadu na skale wykonany przy użyciu mikroskopu optycznego z płuczki zawierającej stabilizator glinowy (A) oraz krzemian sodu (B)

Fig. 7. View of the sediment on the rock made using an optical microscope from a drilling mud containing aluminum stabilizer (A) and sodium silicate (B) porowego przez próbkę skały zależał od rodzaju płuczki, w szczególności od środków chemicznych biorących udział w tworzeniu spolimeryzowanych form glinu i blokowaniu por. Przenikanie filtratu z płuczki sporządzonej na osnowie Al-KHF oraz krzemianu sodu ( $\mathrm{Si}-\mathrm{Na}$ ) zachodziło w porównywalnym czasie, tj. 76 godzin. Natomiast czas przepływu filtratu z płuczki zawierającej Al-KHF, którą skażono $\mathrm{CaCl}_{2}-2 \%$ i $\mathrm{MgCl}_{2}-1 \%$ wynosił 140 godzin (rys. 6). Osady utworzone na próbce skały z płuczki zawierającej Al-KHF oraz z płuczki krzemianowej przedstawiono na rysunku 7. Uzyskane wyniki badań wskazywały na blokowanie por próbki skały, co świadczyłoby, że w warunkach otworowych fizyczno-chemiczne oddziaływanie stabilizatora glinowego powinno zapewnić stabilizację łupków.

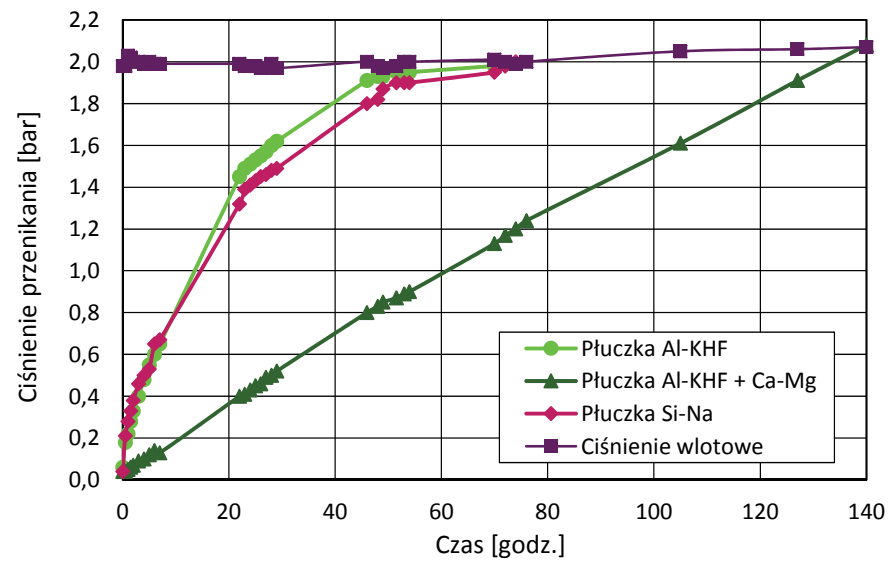

Rys. 6. Test transmisji ciśnienia porowego z wykorzystaniem płuczek zawierających stabilizator glinowy i krzemian sodu

Fig. 6. Test of pore pressure transmission using drilling muds containing aluminum stabilizer and sodium silicate

W celu oceny efektywności uszczelniania przestrzeni porowej skał wykonano także badania filtracji przy użyciu prasy filtracyjnej HPHT i dysków ceramicznych o przepuszczalności $775 \mathrm{mD}$ i $850 \mathrm{mD}$, które sezonowano 24 godz. w solance złożowej o pH 4,4. Badania wykonane zostały w temperaturze 20 i $50^{\circ} \mathrm{C}$, przy ciśnieniu $0,7 \mathrm{MPa}$, a ilość filtratu z płuczki

zawierającej stabilizator glinowy oraz krzemian sodu oznaczono po 10 i 30 min. Przeprowadzone badania wykazały (tabela 1), że w początkowej fazie pomiaru, tj. do $10 \mathrm{~min}$, płuczki charakteryzowały się najwyższą filtracją, głównie w temperaturze $50^{\circ} \mathrm{C}$. Wyższe ilości filtratu odbierano z płuczki zawierającej krzemian sodu. Kolejne już znacznie mniejsze ilości filtratów, w szczególności z płuczki obrobionej stabilizatorem glinowym, które pobierano po $30 \mathrm{~min}$., wskazywały, że tworzone osady uszczelniały pory dysku. Najwyższą skutecznością blokowania charakteryzowała się płuczka zawierająca stabilizator glinowy.

Tabela 1. Wartości filtracji płuczek wiertniczych

Table 1. Filtration values of drilling muds

\begin{tabular}{|c|c|c|c|c|c|}
\hline \multirow[t]{2}{*}{$\begin{array}{c}\text { Rodzaj } \\
\text { dysku }\end{array}$} & \multirow[t]{2}{*}{$\begin{array}{c}\text { Czas } \\
\text { pomiaru } \\
\text { [min] }\end{array}$} & \multicolumn{2}{|c|}{$\begin{array}{c}\text { Filtracja płuczki } \\
\text { zawierającej } \\
\text { stabilizator glinowy } \\
{\left[\mathrm{cm}^{3}\right]}\end{array}$} & \multicolumn{2}{|c|}{$\begin{array}{c}\text { Filtracja płuczki } \\
\text { zawierającej } \\
\text { krzemian sodu } \\
{\left[\mathrm{cm}^{3}\right]}\end{array}$} \\
\hline & & $20^{\circ} \mathrm{C}$ & $50^{\circ} \mathrm{C}$ & $20^{\circ} \mathrm{C}$ & $5^{\circ}{ }^{\circ} \mathrm{C}$ \\
\hline \multirow{3}{*}{$775 \mathrm{mD}$} & 1 & 0 & 0,4 & 0,8 & 2,8 \\
\hline & 10 & 0,6 & 1,6 & 2,4 & 3,4 \\
\hline & 30 & 0,8 & 1,4 & 1,0 & 1,6 \\
\hline \multicolumn{2}{|c|}{ Filtracja całkowita } & 1,4 & 3,4 & 4,2 & 7.8 \\
\hline \multirow{3}{*}{$850 \mathrm{mD}$} & 1 & 0 & 0,8 & 1,2 & 3,2 \\
\hline & 10 & 0,6 & 2,4 & 2,6 & 3,8 \\
\hline & 30 & 0,8 & 0,3 & 1,4 & 1,1 \\
\hline \multicolumn{2}{|c|}{ Filtracja całkowita } & 1,4 & 3,5 & 5,2 & 8,8 \\
\hline
\end{tabular}

Wpływ Al-KHF na właściwości inhibitujące płuczki wiertniczej określono również na podstawie badań pęcznienia wzorcowych skał ilasto-łupkowych, tj. łupku mioceńskiego i eoceńskiego. Zastosowane do badań skały różniły się ilością frakcji ilastej i zawartością w niej minerału mieszanopakietowego illit/smektyt, co miało wpływ na wielkość przyrostu ich objętości w wodzie słodkiej i wybranych roztworach $\mathrm{KCl}$. Przeprowadzone badania wykazały, że przyrost objętości łupku eoceńskiego w wodzie słodkiej wynosił około $20 \%$, a w $10 \%$-owym roztworze $\mathrm{KCl}$ 
około 15\%. Natomiast łupku mioceńskiego w wodzie słodkiej - około 17\% i około 13\% w 7\%-owym roztworze $\mathrm{KCl}$. Badania pęcznienia tych łupków wykonano przede wszystkim z udziałem płuczki zawierającej Al-KHF i dodatkowo obrobionej poliglikolem, czyli Al-KHF + PG, jak również płuczki zawierającej PHPA, poliglikol i KCl (PHPA-PG). Płuczka ta stosowana jest powszechnie w warunkach otworowych do przewiercania skał ilasto-łupkowych różniących się składem mineralogicznym oraz właściwościami fizyczno-mechanicznymi.

Jak wykazały badania, inhibitowane płuczki wiertnicze charakteryzowały się wysoką zdolnością ograniczania pęcznienia zastosowanych do badań próbek skał ilasto-łupkowych w porównaniu do przyrostu ich objętości zarówno w wodzie, jak i w roztworach $\mathrm{KCl}$ (rys. 8-11). Niemniej jednak mniejsze przyrosty objętości tych łupków stwierdzono po oddziaływaniu płuczki bez dodatku glikolu, tj. Al-KHF - głównie łupku mioceńskiego, który pod wpływem wody wykazuje tendencję do dyspersji. Przyrost jego objętości w środowisku płuczki Al-KHF był mniejszy o około $1 \%$ niż w płuczce Al-KHF + PG oraz od około 2 do $4 \%$ niż w roztworach $\mathrm{KCl}$. Natomiast w przypadku łupku eoceńskiego, który można zaliczyć do skał pęczniejących, przyrost jego objętości w środowisku płuczki Al-KHF był porównywalny do przyrostu objętości po oddziaływaniu płuczki Al-KHF + PG oraz 10\%-owego roztworu $\mathrm{KCl}$.

Płuczka z dodatkiem poliglikolu - Al-KHF + PG, która powodowała nieco większe pęcznienie użytych do badań łupków niż płuczka Al-KHF, posiadała większą zdolność ograniczania przyrostu objętości zarówno łupku mioceńskiego, jak i eoceńskiego w porównaniu do płuczki zawierającej w składzie PHPA-PG oraz roztworów $\mathrm{KCl}$ (5 i 7\%). Przyrost objętości łupku mioceńskiego w środowisku płuczki Al-KHF + PG był niższy o około 2\% niż w płuczce PHPA-PG oraz od około 1 do $3 \%$ w roztworach $\mathrm{KCl}$. Natomiast pęcznienie łupku eoceńskiego w środowisku płuczki Al-KHF + PG było niższe

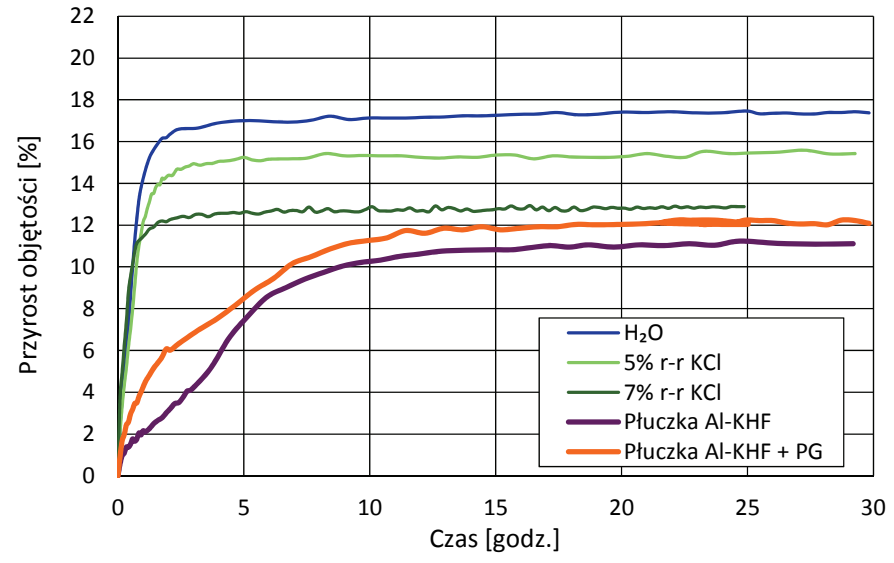

Rys. 8. Pęcznienie lupku mioceńskiego w wodzie, roztworach $\mathrm{KCl}$ oraz płuczkach: Al-KHF i Al-KHF + PG

Fig. 8. Swelling of the Miocene shale in water, $\mathrm{KCl}$ solutions and drilling muds: Al-KHF and Al-KHF + PG o około $1 \%$ niż w płuczce PHPA-PG oraz około 1,3\% niż w 5 i 7\%-owych roztworach $\mathrm{KCl}$.

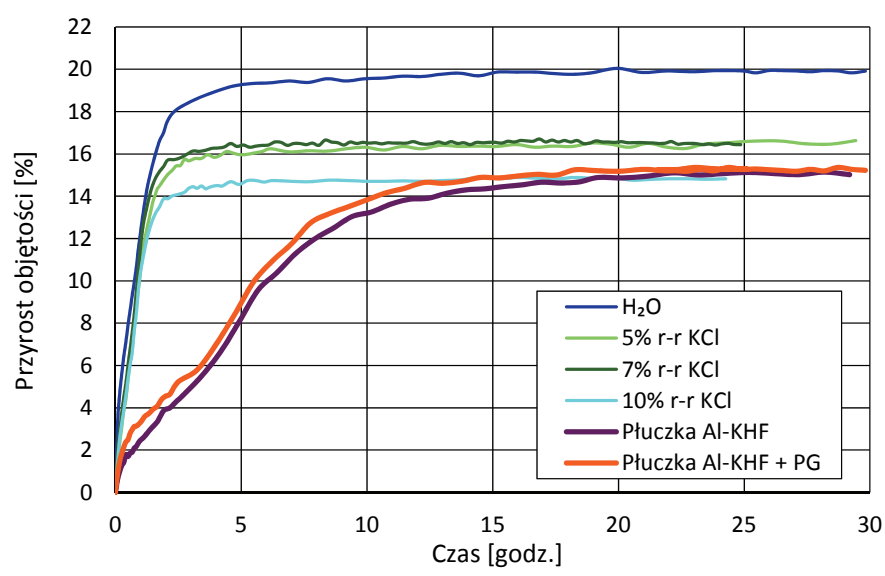

Rys. 9. Pęcznienie lupku eoceńskiego w wodzie, roztworach $\mathrm{KCl}$ oraz płuczkach: Al-KHF i Al-KHF + PG

Fig. 9. Swelling of the Eocene shale in water, $\mathrm{KCl}$ solutions and drilling muds: Al-KHF and Al-KHF + PG

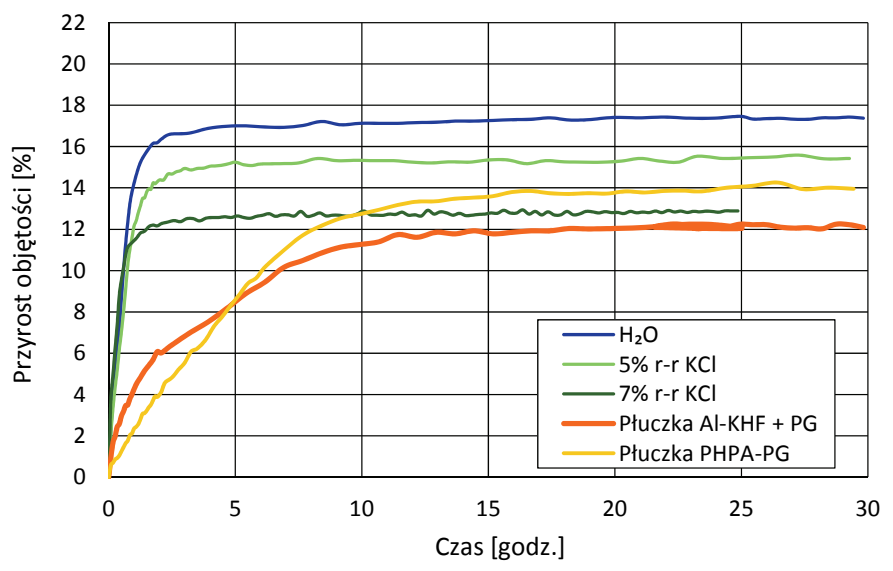

Rys. 10. Pęcznienie lupku mioceńskiego w wodzie, roztworach $\mathrm{KCl}$ oraz płuczkach: Al-KHF + PG i PHPA-PG

Fig. 10. Swelling of the Miocene shale in water, $\mathrm{KCl}$ solutions and drilling muds: Al-KHF + PG and PHPA-PG

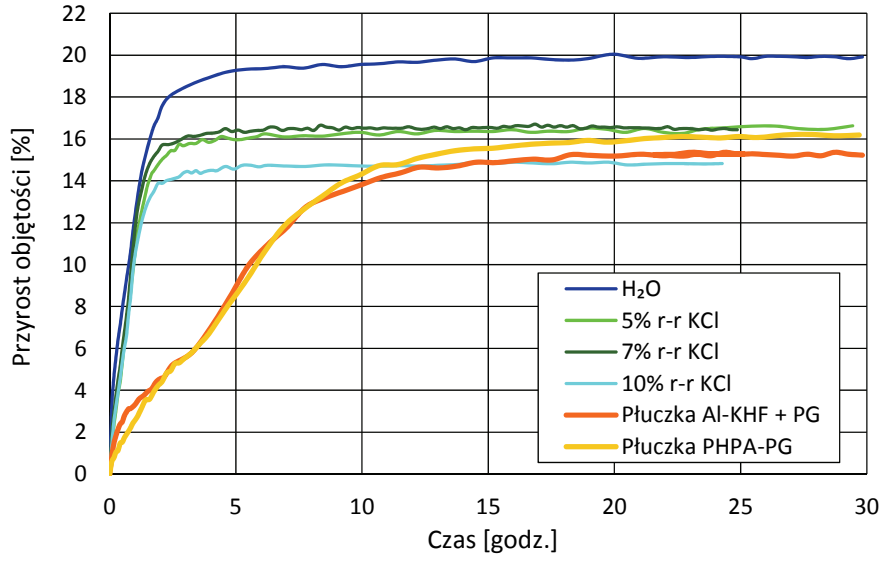

Rys. 11. Pęcznienie lupku eoceńskiego w wodzie, roztworach $\mathrm{KCl}$ oraz płuczkach: Al-KHF + PG i PHPA-PG

Fig. 11. Swelling of the Eocene shale in water, $\mathrm{KCl}$ solutions and drilling muds: Al-KHF + PG and PHPA-PG 


\section{Podsumowanie}

W wyniku przeprowadzonych badań laboratoryjnych opracowano nową odmianę inhibitowanej płuczki wiertniczej na osnowie glinowego stabilizatora łupków, która charakteryzowała się jednorodną i stabilną w czasie zawiesiną koloidalną o właściwościach tiksotropowych, zapobiegającą sedymentacji fazy stałej. Struktura żelowa opracowanej płuczki jest wynikiem wytrącania się w alkalicznym środowisku płuczki polimerowej odmiany glinu, którą mogą być aniony tetrahydroksyglinowe, $\mathrm{AI}(\mathrm{OH})^{-}$, jako produkt dominujący powstający przy wysokich wartościach pH. Wykonane badania wykazały, że:

- do sporządzania płuczki może być stosowana kompozycja środków glinowych w połączeniu ze związkami humusowymi jako stabilizator glinowy, który pełni rolę podstawowego nieorganicznego inhibitora polimerowego - Al-KHF;

- zastosowanie stabilizatora glinowego przyczyniło się do uzyskania unikatowych właściwości reologiczno-strukturalnych płuczki i równoczesnym fizyczno-chemicznym oddziaływaniu jej na skały łupkowe;

- ze względu na powstawanie w warunkach złożowych produktów reakcji stabilizatora glinowego ze skałami i wodami złożowymi, właściwości inhibitujące płuczki powinny być rozpatrywane poprzez metody badawcze określające zmiany ciśnienia porowego w skałach łupkowych;

- płuczka zawierająca stabilizator glinowy charakteryzowała się wysoką zdolnością ograniczania pęcznienia łupku wykazującego tendencję do dyspersji przewyższając efektywnością działania płuczkę o potrójnym inhibitowaniu PHPA-PG;

- $\quad$ synergizm działania stabilizatora glinowego z organicznym inhibitorem polimerowym może być wykorzystany do poprawy właściwości inhibitujących płuczki wiertniczej;

- płuczki zawierające stabilizator glinowy powinny znaleźć zastosowanie do przewiercania warstw łupków kruchych, charakteryzujących się mikroszczelinowością.

Artykuł powstał na podstawie pracy badawczej własnej pt.: Badania nad opracowaniem nowego rodzaju płuczki o właściwościach inhibitacyjnych - praca INiG - PIB; nr zlecenia: 1872/ KW/2016; nr archiwalny: DK-4100-138/2016 oraz pracy badawczej dla przemysłu pt.: Opracowanie systemu płuczki wiertniczej $z$ zastosowaniem wielojonowego i polimerowego inhibitowania hydratacji skat ilasto-łupkowych - INiG - PIB na zlecenie PGNiG; nr zlecenia: 1267/KW/2016, nr archiwalny: DK-4100-197/2016.

\section{Literatura}

Arambulo S., Colque P., Ahmed M., 2015. Case Studies Validate the Effectiveness of Aluminum-based HPWBM in Stabilizing Micro-Fractured Shale Formations: Field Experience in the Peruvian Amazon. Society of Petroleum Engineers. DOI: 10.2118/174854-MS.
Baker Hugnes, 2010. PERFORMAX High-performance water-based fluid system.

Benaissa S., Clapper D.K., Parigot P., Degouy D, 1997. Oilfield Applications of Aluminum Chemistry. Society of Petroleum Engineers. DOI: 10.2118/1197-1194-JPT.

Chao M., Lin Z., Yuansen S., Lun L., 2014. Anti-Collapse Polyamine Aluminum Drilling Fluid System and its Application in Strong Water-Sensitive Shale Formation. EJGE, 19: 2691-2704.

Czerwińska S, Półchłopek T., 1971. Przyczyny występowania trudności wiertniczych w skałach ilastych. Nafta, 8: 264-269.

Dye B., Clapper D., Hansen N., Leaper R., Shoults L., Otto M., Xiang T., Gusler B., 2004. Design Considerations for High Performance Water-Based Muds. AADE-04-DF-HO-14: 1-11.

Krupińska I., 2011. Koagulanty wstępnie zhydrolizowane. Uniwersytet Zielonogórski, Zeszyty naukowe nr 141, Inżynieria Środowiska, 21:126-136.

Krupińska I., 2012. Problemy związane z występowaniem substancji humusowych w wodach podziemnych. Uniwersytet Zielonogórski, Zeszyty Naukowe nr 148, Inżynieria Środowiska, 28: 55-72.

Minczewski J., Marczenko Z., 1985. Chemia analityczna. Tom 1. PWN, Warszawa.

Pastuszko A., 2007. Substancja organiczna w glebach. Ochrona Środowiska i Zasobów Naturalnych, 30: 83-98.

Raczkowski J., Herman Z., Nowotarski I., 1987. Wpływ zjawisk osmotycznych na stateczność ścian otworów wiertniczych. Prace Instytutu Górnictwa Naftowego i Gazownictwa, 63: 1-130.

Raczkowski J., Półchłopek T., 1998. Materiały i środki chemiczne do sporządzania płuczek wiertniczych. Prace Instytutu Górnictwa Naftowego i Gazownictwa, 95: 1-319.

Raczkowski J., Uliasz M., Chudoba J., Półchłopek T., 1996. Płuczka wiertnicza bentonitowo-wodorotlenkowa. Nafta-Gaz, 8: 347-352.

Ramirez M.A, Benalcazar P., Paz D., 2005. The Application of a Salt-Free High Performance Water Base Mud for Minimizing Environmental Impact in The Oriente Ecuadorian Basin. Baker Hughes Drilling Fluids.

Reed M.G., 1972. Stabilization of Formation Clays with HydroxyAluminum Solutions. Journal of Petroleum Technology, July: 860-864.

Siebielska I., Sidełko R., Walendzik B., Kołacz N., Skubała A., 2014. Ocena wykorzystania ekstrakcji za pomoca $\mathrm{NaOH}$ do oznaczania zawartości substancji humusowych w kompostowanym materiale. Politechnika Koszalińska, Inżynieria i Ochrona Środowiska, 17(3): 441-448.

Uliasz M., Chudoba J., Herman Z., 2006. Płuczki wiertnicze z inhibitorami polimerowymi i ich oddziaływanie na przewiercane skały. Prace Instytutu Nafty i Gazu, 139: 1-72.

Zhang S., Qiu Z., Huang W., Cao J., Luo X., 2013a. Characterization of a novel aluminum-based shale stabilizer. Journal of Petroleum Science and Engineering, 103: 36-40.

Zhang S., Qiu Z., Huang W., Cao J., Tang W.Q., Zhong H.Y., 2013b. A Novel Aluminum-based Shale Stabilizer. Petroleum Science and Technology, 31: 1275-1282.

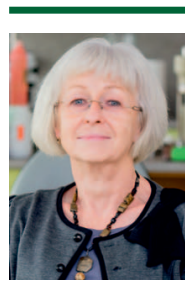

Dr inż. Małgorzata ULIASZ

Kierownik Zakładu Technologii Wiercenia

Instytut Nafty i Gazu - Państwowy Instytut Badawczy ul. Lubicz 25 A

31-503 Kraków

E-mail: malgorzata.uliasz@inig.pl 